\title{
Stigma toward people with mental health problems in Indonesia
}

This article was published in the following Dove Press journal: Psychology Research and Behavior Management

\author{
Nurul Hartini \\ Nur Ainy Fardana \\ Atika Dian Ariana \\ Nido Dipo Wardana \\ Faculty of Psychology, Universitas \\ Airlangga, Surabaya, Indonesia
}

Correspondence: Nurul Hartini Faculty of Psychology, Universitas Airlangga Campus B, Jalan Airlangga 4-6, Surabaya 60286, Indonesia

Email nurul.hartini@psikologi.unair.ac.id
Introduction: Mental health problems are serious issues in Indonesia. The prevalence of severe mental disorder in Indonesian population is $1.7 \%$. In community, people with mental disorder are often stigmatized, while in fact this stigmatization could negatively impact them. One of the most common form of discrimination toward people with mental disorder is the practice of pasung. Method: This research conducted a survey study on 1,269 respondents in East Java (in which the prevalence of severe mental disorder is $2.2 \%$ ). The instruments used were Community Attitudes towards Mental Illness (CAMI), Mental Health Knowledge Schedule (MAKS), and a sociodemographic questionnaire.

Result: The result shows that better knowledge about mental health was associated with lower public stigma toward people with mental disorder. Significance differences in stigma toward people with mental illness were also found across groups of age, sex, experience of contact, history of mental disorder, attitude toward pasung, marital status, and income level.

Conclusion: The finding implies that anti-stigma interventions in Indonesia should consider associated sociodemographic factors and use psychosocial approach to improve literacy and contact with mental health patients.

Keywords: public stigma, people with mental health problem, knowledge, contact, demographic factor, pasung

\section{Introduction}

Mental health problems are a serious issue in Indonesia, including in East Java, a province in the Java Island. According to the national survey or Riset Kesehatan Dasar, ${ }^{1}$ the prevalence of severe mental illnesses such as schizophrenia and other psychotic disorders in East Java is 2.2 per mil. This figure is higher compared to the national prevalence in Indonesia which is 1.7 per mil.

People with mental disorder struggle to heal from illness; yet, they face stigmatization by the society. ${ }^{2}$ Stigma is a negative labeling toward a particular group of people, ${ }^{3}$ which could have deleterious effects on the sufferers of mental disorder. First, stigma shapes a bad image on mental disorders. ${ }^{2}$ Second, it also makes people living with mental illness lose their self-esteem and self-efficacy, as well as preventing them from seeking medical help for their clinical conditions. ${ }^{2,4}$ Furthermore, stigma may result in discrimination against people with mental disorder and prevent them from gaining two important opportunities to pursue their life goals: job opportunity and opportunity to live independently and safely. ${ }^{4}$ Unfortunately, stigma toward people with mental illness has been found not only limited to lay population but also to occur among health professionals like psychiatrists, psychologists, and nurses who work with people with mental disorder. ${ }^{5,6}$ 
One kind of discrimination resulting from stigma toward people with mental illness is the practice of pasung. ${ }^{7.8}$ Pasung is the practice of confining and restraining the mentally ill. In Indonesia, pasung is fairly common. The National Basic Health Research ${ }^{1}$ recorded 1,655 cases of pasung against people with mental disorder in Indonesia. In addition, based on the e-pasung data, ${ }^{9} 2,369$ cases of pasung were recorded in East Java. Pasung is more common in rural areas and is frequently committed by family members with low socioeconomic status. The duration of pasung can range from few days to some years. The most common reason behind the practice of pasung by family of the mentally ill is safety, of both the patient and the community. ${ }^{10,11}$

The enforcement of the Law of Republic of Indonesia number 18 of 2014 concerning mental health has become a trigger for the government's commitment to overcoming issues pertaining to mental disorders, including but not limited to the practice of pasung against people with mental illness. A number of anti-pasung programs have been carried out, such as Indonesia Bebas Pasung (pasung-free Indonesia) and Jawa Timur Bebas Pasung (pasung-free East Java), which were targeted to be accomplished by 2019. In spite of the constant efforts to release mental health patients from pasung, these programs are still considered unsuccessful, which is indicated by the repeated postponement of the accomplishment year of these programs. Initially planned to be completed by 2015 , the accomplishment year of these programs has been changed to 2017 before and is changed to 2019 now. This implies that release of the mentally ill is not enough and a more effective evidence-based strategy is required to eliminate pasung as a product of stigma attached to the mentally ill.

One of the strategies to challenge stigmatic attitudes is by education. ${ }^{12}$ Knowledge is important for changing stigmatic belief against people with mental illness. It can decrease prejudice against mental health patients, raise awareness of mental disorders, and prevent stigmatizing labeling. ${ }^{12}$ While stigma impedes people from seeking and receiving professional treatment, improving knowledge of mental health might offer a solution. ${ }^{5,13}$

Various studies have been conducted on stigma toward people with mental disorder and its relation to demographic characteristics. However, evidence of the relationship between stigma and sociodemographic variables is often inconclusive. For instance, some studies found that younger people can easily accept mentally ill people, ${ }^{14}$ some found that stigmatic attitudes decrease as people become older, ${ }^{15,16}$ and others found no association at all. ${ }^{17}$ Inconclusive results were also found in studies on sex differences in stigma. Some studies found that males are more likely to have more stereotyping and stigmatizing attitudes toward the mentally ill, ${ }^{18}$ some found evidence of females having higher social distance from mental health patients, ${ }^{16}$ and others found no correlation between sex and stigma. ${ }^{14,15}$

Unlike age and gender, the role of education level is less controversial. Higher educational attainment is found to be correlated with more positive attitudes toward the mentally ill. ${ }^{19,20}$ A sociodemographic variable which is often explored in studies about mental health stigma is marital status, but its relation to public stigma toward mental health patients has never been particularly investigated. A meta-analysis showed no significant relationship between being married and self-stigma among mental health patients. ${ }^{21}$

Experience of contact with mental illness is also an important factor. There is a substantial body of evidence showing that level of contact is associated with less stigmatic and discriminating attitudes toward people with mental health problems. ${ }^{16,19,22}$ Increasing level of contact is also a recommended strategy to reduce stigma. ${ }^{12,23}$ In addition to contact with mental health patients, personal experience of mental health problem is also associated with more positive attitudes..$^{24,25}$ People who have gone through a mental health disorder themselves are found to be more familiar with mental illness and have less stigmatic attitudes.

Although studies on stigma, knowledge, and sociodemographic variables are quite common, there is a limited body of literature of such studies in Indonesia. The available evidence of cultural difference ${ }^{26,27}$ demonstrated by studies on stigma suggests the necessity to conduct similar studies in Indonesia as the results may differ due to different cultural context from those of the previous studies. Therefore, this research aimed to explore the correlation between knowledge about mental health and stigma toward people with mental disorders and to find whether there is any marked difference in stigma toward people with mental illness across groups of age, sex, marital status, monthly income, education, experience of contact, history of mental disorder, and attitude toward pasung.

\section{Methods}

\section{Sample}

This survey research involved 1,269 respondents. The respondents ranged from 10 to 75 years of age, with an average age of 23.3 years. The majority of the respondents $(63.6 \%)$ were female, while $35 \%$ were male and the remaining $1.4 \%$ preferred not to say.

\section{Measures}

\section{Community Attitudes toward Mental Illness (CAMI)}

This research used CAMI to measure respondents' attitudes toward people with mental disorder. CAMI is a 40 -item scale 
developed by Taylor and Dear, ${ }^{28}$ consisting of four subscales, namely authoritarianism, social restrictiveness, benevolence, and community mental health ideology. High score in authoritarianism and social restrictiveness subscales implies negative or stigmatic attitude toward people with mental disorder, while high score in benevolence and community mental health ideology subscales is associated with positive attitude.

\section{Mental Health Knowledge Schedule (MAKS)}

MAKS was used in this research to measure the respondents' knowledge about mental health and mental disorders. It was developed by Evans-Lacko et al, ${ }^{29}$ comprising two sets of items, each of which consists of six items. The first set aims to assess stigma-related knowledge areas, and the second set measures level of recognition and familiarity with various conditions. ${ }^{29}$ This research used only the first set of items as it is the most relevant part to use in this study.

\section{Sociodemographic questionnaire}

Respondents were asked to provide information about their age, sex, marital status, latest education, monthly income, experience of contact with patients of mental disorder, history of mental disorder, and attitude toward the practice of pasung.

\section{Procedures}

Data collection was conducted from June to September 2017 in East Java. The survey was carried out door-to-door by trained surveyors using accidental sampling technique. Prior to data collection, participants were given a consent form they needed to sign. Underage participants were accompanied by adult relatives or guardians during completion of the questionnaires.

\section{Analysis}

A correlational analysis was conducted to explore the relationship between knowledge about mental health, attitudes toward people with mental disorders, and demographic characteristics. Independent sample $t$-test and ANOVA were also run to examine significant differences in level of knowledge about mental health, and contact with and attitudes toward people with mental disorder across groups of demographic characteristics.

\section{Results}

\section{Demographics of the respondents}

Table 1 shows the demographic characteristics of the respondents. The age of the respondents varied from 10 to 75 years with a mean age of 23.3 years. Of the respondents, 444 (35\%) were male and $807(63.6 \%)$ were female.
In terms of educational level, the majority of the respondents $(72.3 \%)$ had a high school education or lower, $24 \%$ were undergraduates, $3.4 \%$ had diploma, and $0.3 \%$ were postgraduates. In terms of marital status, 1,036 (81.6\%) respondents were single, $195(15.4 \%)$ were married, and $18(1.4 \%)$ were divorced. In terms of economic status, the majority of the respondents (59.3\%) had a monthly income of less than Indonesian rupiah (IDR) 2.2 million, $12.2 \%$ of the respondents had a monthly income of IDR 2.2-3.5 million, 6.8\% earned IDR 3.5-4.6 million per month, 6.4\% earned IDR 4.6-8 million per month, and 5.1\% earned more than IDR 8 million per month.

Based on this demographic distribution, the participants involved in this research were fairly representative of the population. The majority of the respondents had low educational attainment and monthly income, indicating people of low socioeconomic status among whom pasung cases are commonly found. ${ }^{10,11}$ However, the ratios of sex and marital group were rather disproportionate.

\section{Results of data analysis}

Statistical analysis was run to test the hypotheses of the current research. First, correlational analysis was conducted to find out any significant correlation between knowledge

Table I Demographics of the respondents

\begin{tabular}{|l|l|l|}
\hline Demographics & $\mathbf{N}$ & Percentage \\
\hline $\begin{array}{l}\text { Age: I0-75 years old, mean: 23.3 } \\
\text { Sex }\end{array}$ & 1,269 & 100 \\
$\quad$ Male & 444 & \multicolumn{1}{l|}{} \\
Female & 807 & 63.6 \\
Missing & 18 & 1.4 \\
\hline Education & 918 & 72.3 \\
\hline High school or lower & 43 & 3.4 \\
Diploma & 304 & 24.0 \\
Undergraduate & 4 & 0.3 \\
Postgraduate & \multicolumn{2}{|l}{} \\
\hline Marital status & 1,036 & 81.6 \\
\hline Single & 195 & 15.4 \\
Married & 18 & 1.4 \\
Divorced & 20 & 1.6 \\
Missing & \multicolumn{2}{|l}{} \\
\hline Monthly income (million) & 752 & 59.3 \\
\hline <IDR 2.2 & 155 & 12.2 \\
IDR 2.2-3.5 & 86 & 6.8 \\
IDR 3.5-4.6 & 81 & 6.4 \\
IDR 4.6-8 & 65 & 5.1 \\
>IDR 8 & 130 & 10.2 \\
Missing & \multicolumn{2}{|l}{} \\
\hline
\end{tabular}

Abbreviation: IDR, Indonesian rupiah. 
on mental health (as measured by MAKS), age, and stigma toward people with mental disorder (as measured by CAMI).

Table 2 indicates that there was a weak yet marked correlation between age and level of stigma toward people with mental illness and between knowledge of mental health and stigma. Both correlations were negative suggesting that an increase in one variable co-occurred with a decrease in the other variable.

The second statistical analysis aimed to examine any score differences in level of stigma across groups of sociodemographic factors (ie, contact with patients of mental disorder, history of mental disorder in family, attitude toward pasung, sex, level of education, marital status, and monthly income).

Tables 3 and 4 show some score differences in level of stigma toward people with mental illness across groups of contact experience, history of mental disorders or symptoms in family, attitude toward pasung, sex, marital status, and level of income. Meanwhile, no marked score differences in level of stigma were found across groups of education level.

Post hoc analysis found score differences in attitude toward people with mental health between single and married respondents. No significant differences were found between single and divorced respondents or between married and divorced individuals. Furthermore, post hoc analysis of income level showed notable differences between respondents who earned less than IDR 2.2 million and those who earned IDR 2.2-3.5 million a month, between individuals whose monthly income was less than IDR 2.2 million and those

Table 2 Correlation between knowledge, age, and stigma

\begin{tabular}{|l|l|l|l|}
\hline Spearman's rho correlation & $\rho$ & $\mathbf{P}$ & $\mathbf{N}$ \\
\hline CAMI score $\times$ age & -0.14 & $<0.0 \mathrm{I}$ & $\mathrm{I}, 248$ \\
CAMI score $\times$ MAKS score & -0.17 & $<0.0 \mathrm{I}$ & $\mathrm{I}, 268$ \\
\hline
\end{tabular}

Abbreviations: CAMI, Community Attitudes toward Mental Illness; MAKS, Mental Health Knowledge Schedule. whose monthly income was IDR 4.6-8 million, as well as between individuals with a monthly income of IDR 2.2-3.5 million and those with a monthly income of more than IDR 8 million.

\section{Declaration}

Ethical approval was obtained from The Board of Ethics, Faculty of Psychology, Universitas Airlangga, prior to the study. All participants and parents of the participants aged under 18 years old were required to sign the informed consent that had been previously explained or informed by the researcher.

\section{Discussion}

Statistical analysis showed that knowledge about mental health significantly correlated with stigma toward mental health patients $(\rho=-0.17, P<0.01)$. In addition to the weak correlation, the correlation between both variables was negative in nature. This suggests that the better knowledge individuals have about mental health, the lower their tendency to have stigmatic attitude toward people with mental disorders.

This finding supports the results of previous studies which suggest that lack of knowledge on mental health or mental health literacy is one of the sources of stigma. ${ }^{30}$ Low mental health literacy is known to have repercussions both on oneself (eg, being unprepared to correctly decide what to do when one feels symptoms related to mental health problem) and on other people (eg, resistance to interact with mental health patients). A previous study showed that well-literate individuals in terms of mental health knowledge tend to have better attitude toward people with mental disorder. ${ }^{31}$ Therefore, previous studies recommend psychoeducational programs through a variety of methods to reduce stigma toward mental health patients in the society. ${ }^{23,26,32}$ Psychosocial interventions, such as

Table 3 Differences in stigma level across experience of contact, history of mental problem, attitude toward pasung, and sex

\begin{tabular}{|c|c|c|c|c|}
\hline Binomial sociodemographic factor & $\mathbf{N}$ & Mean (SE) & $t(d f)$ & $P$-value \\
\hline Experience of contact & & & $-4.27 I(I, 26 I)$ & $<0.01$ \\
\hline Yes & 549 & $136.26(0.658)$ & & \\
\hline No & 714 & I39.87 (0.544) & & \\
\hline History of mental disorder & & & $-2.919(1,262)$ & $<0.01$ \\
\hline Yes & 1,191 & $138.02(0.432)$ & & \\
\hline No & 73 & $143.29(1.836)$ & & \\
\hline Attitude toward pasung & & & $4.852(1,259)$ & $<0.01$ \\
\hline Not supportive & 1,192 & I $38.82(0.430)$ & & \\
\hline Supportive & 69 & I29.87 (I.87I) & & \\
\hline Sex & & & $-2.193(1,249)$ & $<0.05$ \\
\hline Male & 444 & $137.15(0.695)$ & & \\
\hline Female & 807 & $139.09(0.534)$ & & \\
\hline
\end{tabular}


Table 4 Differences in stigma level across educational level, marital status, and income level

\begin{tabular}{|l|l|l|l|}
\hline Polynomial sociodemographic factor & N & Mean (SE) & F (df) \\
\hline Education & & & I.value \\
$\quad$ High school or lower & 918 & $138.71(0.496)$ & \\
$\quad$ Diploma & $43.1268)$ & \\
Undergraduate & 304 & $134.53(2.225)$ & \\
Postgraduate & 4 & $137.56(0.862)$ & \\
Marital status & & $139.75(3.816)$ & \\
Single & 1,036 & $139.35(0.462)$ & \\
Married & 195 & $133.58(1.079)$ & \\
$\quad$ Divorced & 18 & $136.06(2.572)$ & \\
Monthly income (million) & & & \\
$\quad<$ IDR 2.2 & 752 & $140.03(0.524)$ & \\
IDR 2.2-3.5 & 155 & $134.52(1.131)$ & \\
IDR 3.5-4.6 & 86 & $136.60(1.659)$ & \\
IDR 4.6-8 & 81 & $135.16(1.761)$ & \\
>IDR 8 & 65 & $141.03(2.260)$ & \\
\hline
\end{tabular}

Abbreviation: IDR, Indonesian rupiah.

family support toward people with mental illness, are also believed to be able to reduce stigma and improve health service toward mental health patients. ${ }^{33,34}$

This research also found significant score differences in level of stigma toward people with mental illness based on contact experience $(t=-4.271, P<0.01)$ and history of mental disorder within family $(t=-2.919, P<0.01)$. Familiarity with mental disorder was found to have notable contribution to the shaping of attitude toward mental health patients. ${ }^{26}$ The more familiar individuals with mental illness, the lower their inclination to avoid mental health patients. Familiarity in this case means the extent to which individuals are exposed to mental health patients, ranging from never meeting someone with mental disorder to having severe mental illness themselves. ${ }^{35}$

Age was found to have a negative correlation with stigma toward people with mental illness ( $\rho=-0.14$, $P<0.01)$. This means that as people become older, they will be more tolerant toward mental health patients. This finding is similar to that of the study by Adewuya and Oguntade ${ }^{16}$ which found that younger individuals tended to have more stigmatic attitude toward people with mental disorder compared to older individuals. It was assumed that older individuals had a wider range of life experiences which led them to better accept the differences and uniqueness of others, and hence better accept the presence of mental health patients. Similar explanation also applies to those who have a spouse. Marriage is deemed to be an experience which allows an individual to progressively accept the differences and uniqueness of other people. This is particularly the case with couples who live together.
Therefore, married individuals have more tolerant attitude toward people with mental disorder compared to single or divorced individuals.

Statistical analysis of other demographic factors found some score differences in level of stigma across groups of sex, attitude toward pasung, and level of income. Meanwhile, education level was found to have no marked contribution to the score difference in level of stigma toward mental health patients. This finding implies that public attitude toward people with mental illness is not associated with an individual's educational background. This is in line with previous studies which found that sociodemographic factors significantly contributed to the shaping of attitude toward individuals with mental disorders. ${ }^{2,6,36,37}$

\section{Limitations}

This research has two limitations. First, it used translated versions of scales developed in Western culture which were never used for general samples in Indonesia. Second, like other studies that use self-report measurement, the results of this research might be limited in terms of spontaneity and uncontrolled nature of the subjects' responses.

\section{Conclusion}

A marked negative correlation between level of knowledge about mental health and level of stigma toward people with mental health in community was found. In addition to that, score differences were found in level of stigma associated with age, sex, experience of contact, history of mental health, attitude toward pasung, marital status, and income per month. 
Systemic anti-stigma intervention is recommended through psychosocial approach emphasizing efforts to improve mental health literacy and contact with mental health patients. The society should develop more positive or tolerant attitude toward people with mental illness and should support the realization of anti-pasung programs.

\section{Disclosure}

The authors report no conflicts of interest in this work.

\section{References}

1. Badan Penelitian dan Pengembangan Kesehatan [National Institute of Health Research and Development]. Riset Kesehatan Dasar [Basic Health Research]. Jakarta; 2013. Available from: http://www.depkes. go.id/resources/download/general/Hasil\%20Riskesdas\%202013.pdf. Indonesian.

2. Rüsch N, Angermeyer MC, Corrigan PW. Mental illness stigma: concepts, consequences, and initiatives to reduce stigma. Eur Psychiatry. 2005;20(8):529-539.

3. Hayward P, Bright JA. Stigma and mental illness: A review and critique. J Ment Health. 1997;6(4):345-354.

4. Corrigan PW, Kerr A, Knudsen L. The stigma of mental illness: Explanatory models and methods for change. Appl Prev Psychol. 2005;11(3):179-190.

5. Jorm AF. Mental health literacy. Public knowledge and beliefs about mental disorders. Br J Psychiatry. 2000;177:396-401.

6. Üçok A. Other people stigmatize ... but, what about us? Attitudes of mental health professionals towards patients with schizophrenia. In: Alboleda-Flórez J, Sartorius N, editors. Understanding the Stigma of Mental Illness: Theory and Interventions. West Sussex: John Wiley \& Sons Ltd; 2008:108-116.

7. Mayville E, Penn DL. Changing societal attitudes toward persons with severe mental illness. Cogn Behav Pract. 1998;5(2):241-253.

8. Lestari W, Wardhani YF. Stigma and Management on People with Severe Mental Disorders with "Pasung" (Physical Restraint). Bul Penelit Sist Kesehat. 2014;17:157-1662.

9. Rekap Keseluruhan Data Pasung Provinsi Jawa Timur [Recapitulation of pasung data in East Java province]. Available from: http://wtpc.net/epasung/rekap/keseluruhan. Indonesian. Accessed January 13, 2017.

10. Minas H, Diatri H. Pasung: Physical restraint and confinement of the mentally ill in the community. Int J Ment Health Syst. 2008;2(1):8.

11. Puteh I, Marthoenis M, Minas H. Aceh Free Pasung: Releasing the mentally ill from physical restraint. Int J Ment Health Syst. 2011;5:10-15.

12. Corrigan PW, Shapiro JR. Measuring the impact of programs that challenge the public stigma of mental illness. Clin Psychol Rev. 2010;30(8):907-922.

13. Jorm AF. Mental health literacy: empowering the community to take action for better mental health. Am Psychol. 2012;67(3):231-243.

14. Johnson PJ, Beditz J. Community support systems: scaling community acceptance. Community Ment Health J. 1981;17(2):153-160.

15. Chee CY, Ng TP, Kua EH. Comparing the stigma of mental illness in a general hospital with a state mental hospital: a Singapore study. Soc Psychiatry Psychiatr Epidemiol. 2005;40(8):648-653.

16. Adewuya AO, Oguntade AA. Doctors' attitude towards people with mental illness in Western Nigeria. Soc Psychiatry Psychiatr Epidemiol. 2007;42(11):931-936.

17. Wolff G, Pathare S, Craig T, Leff J. Community knowledge of mental illness and reaction to mentally ill people. $B r J$ Psychiatry. 1996;168(2):191-198.
18. Ng P, Chan KF. Sex differences in opinion towards mental illness of secondary school students in Hong Kong. Int $J$ Soc Psychiatry. 2000;46(2):79-88.

19. Papadopoulos C, Leavey G, Vincent C. Factors influencing stigma: a comparison of Greek-Cypriot and English attitudes towards mental illness in north London. Soc Psychiatry Psychiatr Epidemiol. 2002;37(9): 430-434.

20. Song LY, Chang LY, Shih CY, Lin CY, Yang MJ. Community attitudes towards the mentally ill: the results of a national survey of the Taiwanese population. Int J Soc Psychiatry. 2005;51(2):162-176.

21. Livingston JD, Boyd JE. Correlates and consequences of internalized stigma for people living with mental illness: a systematic review and meta-analysis. Soc Sci Med. 2010;71(12):2150-2161.

22. Francis C, Pirkis J, Dunt D, Blood R.W, Davis C. Improving mental health literacy: a review of the literature. 2002. Available from: http:// www.childhealthresearch.eu/research/add-knowledge/Literature reveiw on mental health literacy strategies 2002.pdf.

23. Corrigan PW, Morris SB, Michaels PJ, Rafacz JD, Rüsch N. Challenging the public stigma of mental illness: a meta-analysis of outcome studies. Psychiatr Serv. 2012;63(10):963-973.

24. Angermeyer MC, Matschinger $\mathrm{H}$. The effect of personal experience with mental illness on the attitude towards individuals suffering from mental disorders. Soc Psychiatry Psychiatr Epidemiol. 1996;31(6):321-326.

25. Angermeyer MC, Dietrich S. Public beliefs about and attitudes towards people with mental illness: a review of population studies. Acta Psychiatr Scand. 2006;113(3):163-179.

26. Corrigan PW, Edwards AB, Green A, Diwan SL, Penn DL. Prejudice, social distance, and familiarity with mental illness. Schizophr Bull. 2001;27(2):219-225.

27. Mellor D, Carne L, Shen YC, McCabe M, Wang L. Stigma Toward Mental Illness: A Cross-Cultural Comparison of Taiwanese, Chinese Immigrants to Australia and Anglo-Australians. J Cross Cult Psychol. 2013;44(3): 352-364.

28. Taylor SM, Dear MJ. Scaling community attitudes toward the mentally ill. Schizophr Bull. 1981;7(2):225-240.

29. Evans-Lacko S, Little K, Meltzer H, et al. Development and psychometric properties of the Mental Health Knowledge Schedule. Can J Psychiatry. 2010;55(7):440-448.

30. Wahl OF, Susin J, Kaplan L, Lax A, Zatina D. Changing Knowledge and Attitudes with a Middle School Mental Health Education Curriculum. Stigma Res Action. 2011;1(1):44-53.

31. Dahlberg KM, Waern M, Runeson B. Mental health literacy and attitudes in a Swedish community sample - Investigating the role of personal experience of mental health care. BMC Public Health. 2008;8(1):1-10.

32. Couture SM, Penn DL. Interpersonal contact and the stigma of mental illness: A review of the literature. J Ment Health. 2003;12(3):291-305.

33. Setyanto AT, Hartini N, Alfian IN. Penerapan social support untuk meningkatkan Kemandirian pada penderita Skizofrenia [Implementation of social support to improve independence of schizophrenia patients]. J Wacana. 2017;9(1):91-115. Indonesian [with English abstract].

34. Hartini N, Ariana AD, Dewi TK, Kurniawan A. Improving urban environment through public commitment toward the implementation of clean and healthy living behaviors. Psychol Res Behav Manag. 2017;10:79-84.

35. Holmes EP, Corrigan PW, Williams P, Canar J, Kubiak MA. Changing attitudes about schizophrenia. Schizophr Bull. 1999;25(3):447-456.

36. Levav I. Corrigan PW, Roe D, Tsang HWH: Challenging the Stigma of Mental Illness: Lessons for Therapists and Advocates. John Wiley \& Sons; 2011.

37. Pinto-Foltz MD, Logsdon MC, Myers JA. Feasibility, acceptability, and initial efficacy of a knowledge-contact program to reduce mental illness stigma and improve mental health literacy in adolescents. Soc Sci Med. 2011;72(12):2011-2019. 


\section{Publish your work in this journal}

Psychology Research and Behavior Management is an international, peerreviewed, open access journal focusing on the science of psychology and its application in behavior management to develop improved outcomes in the clinical, educational, sports and business arenas. Specific topics covered in the journal include: Neuroscience, memory and decision making; Behavior
Submit your manuscript here: https://www.dovepress.com/psychology-research-and-behavior-management-journal modification and management; Clinical applications; Business and sports performance management; Social and developmental studies; Animal studies. The manuscript management system is completely online and includes a very quick and fair peer-review system, which is all easy to use. Visit http://www. dovepress.com/testimonials.php to read real quotes from published authors. 